\title{
Increased adhesion of Escherichia coli to mucosal cells from infants with protracted diarrhoea: a possible factor in the pathogenesis of bacterial overgrowth and diarrhoea
}

\author{
D C A CANDY, TERESA S M LEUNG, W C MARSHALL, AND J T HARRIES* \\ From The Institute of Child Health and The Hospital for Sick Children, Great Ormond Street, London
}

SUMmaRY Mucosal adhesion of bacteria has been studied in eight infants with protracted diarrhoea and malnutrition, using a buccal epithelial cell technique. A known non-adhesive strain of Escherichia coli $(\mathrm{O} 1: \mathrm{K} 1: \mathrm{H} 7)$ adhered to a significantly greater $(\mathrm{p}<0.001)$ proportion of buccal epithelial cells from patients with protracted diarrhoea, compared with children with acute diarrhoea, healthy infants, and healthy adults. Also, Enterobacteria isolated from the jejunum or stools of patients with protracted diarrhoea adhered to far greater numbers of their own buccal epithelial cells compared with healthy adults. These results suggest that bacterial adhesion may play an important role in the pathogenesis of protracted diarrhoea.

Diarrhoea is one of the leading causes of mortality and morbidity in young children throughout the world, particularly in the developing countries where the diarrhoea/malnutrition interaction is so common. ${ }^{1-6}$

Although the pathophysiological mechanisms operating in the genesis of the diarrhoea are poorly understood, bacterial overgrowth of the small intestine in such patients is common. ${ }^{2-7}$ Adhesion of bacteria to the mucosal surface is probably an essential prerequisite to their proliferation within the small intestine and therefore to their capacity to induce disease. ${ }^{8}$

In this paper, we report our findings of studies of adhesion of a previously studied strain of $E$ coli $^{9}$ to buccal epithelial cells from infants with protracted diarrhoea and malnutrition. The preliminary results have been included in a previous communication. ${ }^{10}$

\section{Methods}

\section{SUBJECTS}

Protracted diarrhoea is defined as the passage of four or more watery stools per day for a period of more than two weeks during which time there is no

Address for correspondence: Dr W C Marshall. Department of Child Health. Institute of Child Health. 30 Guildford Street. London WCIN IEH.

Recicicd for publication 27 August 1982

- Since this paper was submitted Professor Harries has unfortunately died. weight gain or loss of weight. ${ }^{\prime \prime}$

Eight patients with protracted diarrhoea aged between three and 44 weeks (mean age on admission 21 weeks) were studied in whom investigations failed to reveal an established cause for the diarrhoea. All were below the third centile for weight and two of the patients subsequently died (Table 1). Jejunal biopsies were normal in four, the fifth had partial villous atrophy; biopsies were not performed in the remaining three patients. Anaerobic and aerobic cultures of jejunal fluid were performed in four patients and all had viable counts of $10 \% / \mathrm{ml}$ or more of Enterobacteriaceae.

In order to control the study three other groups of subjects were studied: (1) Ten children aged one to 22 months (mean 8.4 months) who developed acute diarrhoea. Serotypable strains of $E$ coli $^{12}$ were isolated from the stools of each of the 10 children; viruses were not visible on electronmicroscopy in any of the patients. (2) Thirteen healthy infants aged four to 24 months (mean 9.2 months) who were attending an infant welfare clinic. (3) Ten healthy adults.

ADHESION ASSAY

Bacterial adhesion to buccal epithelial cells was studied by a modification of the method of Ofek $e t$ $a l^{13}$ as described by Candy et $a l^{14}$ and the percentage of buccal epithelial cells with adhering gram- 
Table 1 Clinical details, jejunal mucosal morphology, and jejunal fluid culture results in the infants with protracted diarrhoea

\begin{tabular}{|c|c|c|c|c|c|c|c|}
\hline \multirow[b]{2}{*}{ Patient } & \multicolumn{2}{|c|}{ Age (weeks) } & \multirow{2}{*}{$\begin{array}{l}\text { Weight on } \\
\text { admission } \\
(\mathrm{kg})\end{array}$} & \multirow[b]{2}{*}{$\begin{array}{l}\text { Jejunal } \\
\text { biopsy }\end{array}$} & \multicolumn{2}{|c|}{ Jejunal fluid culture } & \multirow{2}{*}{$\begin{array}{l}\text { Age (months } \\
\text { at discharge } \\
\text { or death }\end{array}$} \\
\hline & Onset & Admission & & & $\begin{array}{l}\text { Coliform } \\
\text { species }\end{array}$ & $\begin{array}{l}\text { Viable count } \\
\text { (organisms } / m l \text { ) }\end{array}$ & \\
\hline 1 & 2 & 3 & $2 \cdot 3$ & $\mathrm{~N}$ & E coli & $4.3 \times 10^{6}$ & $25^{+}$ \\
\hline 2 & 2 & 20 & $3 \cdot 3$ & $\mathbf{N}$ & P mirabilis & $1.4 \times 10^{5}$ & 29 \\
\hline 3 & 3 & 44 & $7 \cdot 5$ & $\mathrm{~N}$ & Ecloacae & $1.4 \times 10^{5}$ & 13 \\
\hline 4 & 17 & 40 & $7 \cdot 4$ & $\mathrm{~N}$ & - & - & 11 \\
\hline 5 & 24 & 25 & $4 \cdot 2$ & PVA & E coli & $1.0 \times 10^{5}$ & 8 \\
\hline 6 & 1 & 1 & $2 \cdot 8$ & - & - & - & $5^{+}$ \\
\hline 7 & 20 & 33 & $3 \cdot 5$ & - & - & - & 9 \\
\hline 8 & 4 & 4 & $2 \cdot 9$ & - & - & - & 2 \\
\hline
\end{tabular}

$\mathrm{N}=$ normal. PVA $=$ partial villous atrophy.

negative bacilli was recorded by examining 100 cells by light microscopy. In all experiments a 'cell control' was included in which the buccal epithelial cells were incubated in the absence of bacteria.

\section{BACTERIA}

E coli $\mathrm{O} 1: \mathrm{K} 1: \mathrm{H} 7$ which does not adhere to human fetal intestine, ${ }^{9} E$ coli (untypable), cultured from the upper small intestinal juice of case 1 , Proteus mirabilis and $E$ cloacae from cases 2 and 3 respectively, and $E$ coli serogroups $\mathrm{O} 111$ and $\mathrm{O} 119$ cultured from the stools of cases $4,6,7$, and 8 were studied (Table 2).

$E$ coli $\mathrm{O} 1: \mathrm{K} 1: \mathrm{H} 7$ was studied with buccal epithelial cells from both the patients and the other three groups. The bacteria isolated from the patients with protracted diarrhoea were studied with buccal epithelial cells from the patients and from a healthy adult volunteer.

Table 2 Adhesion of Enterobacteria isolated from infants with protracted diarrhoea

\begin{tabular}{|c|c|c|c|}
\hline \multirow[b]{2}{*}{ Patient } & \multirow[b]{2}{*}{ Enterobacteria } & \multicolumn{2}{|c|}{ \% Adhesion } \\
\hline & & Patient' & Adult $\neq$ \\
\hline 1 & $E$ coli (non-agglutinable) ${ }^{*}$ & 86 & 52 \\
\hline 2 & $P$ mirabilis* & 98 & 59 \\
\hline 3 & E cloacae $^{*}$ & 90 & 4 \\
\hline 4 & E coli $\mathrm{O} 111$ & 100 & 9 \\
\hline 5 & E coli $\mathrm{O} 119$ & 60 & 9 \\
\hline 6 & E coli $\mathrm{O} 111$ & 83 & NT \\
\hline 7 & E coli $\mathrm{O} 1, \mathrm{O} 111$ & 9 & 0 \\
\hline
\end{tabular}

* Jejunum isolates.

+ Tested with buccal epithelial cells from patient from whom the Enterobacteria were isolated.

$\ddagger$ Tested with buccal epithelial cells from a healthy adult (different adult donor used in each test).

NT $=$ not tested.

\section{HAEMAGGLUTINATION TESTS}

Enterobacteria were screened for colonisation factors I and II (CFA/I and CFA/II) by mannoseresistant haemagglutination of species-appropriate erythrocytes ${ }^{15}$ and for Type I fimbriae by mannosesensitive agglutination of guinea pig erythrocytes. ${ }^{15}$

\section{STATISTICAL METHODS}

The significance of differences between results in the various groups studied was assessed using the $\chi^{2}$ test.

\section{Results}

\section{ADHESION OF E COLI O1:K1:H7 (Figure)}

E coli $\mathrm{O} 1: \mathrm{K} 1: \mathrm{H} 7$ adhered to $18-96 \%$ of buccal epithelial cells from the infants with protracted diarrhoea, 0-24\% from those with acute diarrhoea, $0-41 \%$ of healthy infants, and $0-8 \%$ of healthy adults. The proportion of subjects with $E$ coli adhering to $25 \%$ or more buccal epithelial cells was seven of eight with protracted diarrhoea, none of 10 with acute diarrhoea, two of 13 healthy infants, and none of the adults. Thus this known non-adhesive strain of $E$ coli adhered to $25 \%$ or more of buccal epithelial cells from a significantly greater proportion of infants with protracted diarrhoea compared with each of the other groups $(p<0.001)$.

\section{ADHESION OF ENTEROBACTERIA ISOLATED FROM}

THE JEJUNUM OR STOOLS OF INFANTS WITH

PROTRACTED DIARRHOEA (Table 2)

Six of the seven strains of Enterobacteria adhered to $50 \%$ or more of buccal epithelial cells from the patients from whom they were tested. Bacteria from six of the patients were then tested with bucial epithelial cells from healthy adult donors, and only two of the strains adhered to more than $50 \%$ buccal epithelial cells. 


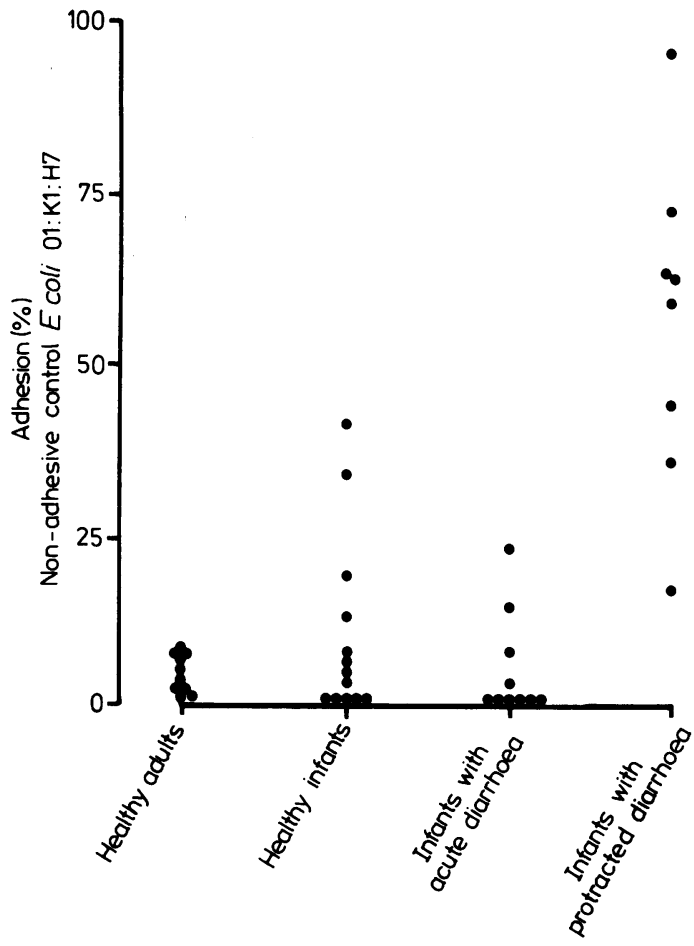

Figure* Adhesion of the non-adhesive control E coli (O1:K1:H7) to buccal epithelial cells from adults, infants with acute diarrhoea, and infants with protracted diarrhoea.

\section{HAEMAGGLUTINATION}

The seven strains of Enterobacteria were negative when tested for CFA/I and CFA/II production. $E$ coli from patients 1 and 8 produced Type I fimbriae.

\section{Discussion}

Severe life-threatening diarrhoea in piglets may result from infection by a strain of $E$ coli which possesses a surface antigen designated $\mathrm{K} 88$, which mediates adhesion of the organism to the small intestinal mucosa. ${ }^{16}$ The role of the host cells in the adhesive interaction between bacteria and mucosal cells was first emphasised by Rutter et $a l^{17}$ who showed that this K88 strain was unable to adhere to isolated brush borders of piglets from certain litters, and that this non-adhesive phenotype was inherited in an autosomal recessive fashion. Moreover, these piglet litters were relatively resistant to developing diarrhoea when administered the K88 E coli, thus highlighting not only the importance of adhesion as a prerequisite for colonisation of the intestine in the

* We are grateful to the CIBA Foundation for permission to reproduce the Figure taken from a paper ${ }^{10}$ resulting from CIBA Symposium 80 on adhesion and microorganism pathogenicity. genesis of the diarrhoea induced by this bacteria, but also the importance of host cells in adhesion.

Similar conclusions can be drawn from two human studies. Kallenius and Winberg ${ }^{18}$ showed that a known pyelonephritic strain of $E$ coli adhered in greater numbers to periurethral cells from girls with recurrent, unexplained urinary tract infections; moreover, the cells had greater numbers of bacteria adhering to them in vivo compared with controls. Patients in intensive care units have also been studied using buccal epithelial cells and again patients with pharyngeal colonisation with gramnegative bacteria, particularly Proteus and Pseudomonas, had more gram-negative bacteria adhering to their buccal epithelial cells in vivo, and more Pseudomonas adhered to buccal epithelial cells from these patients in vitro, compared with patients who did not become colonised with gramnegative bacteria. ${ }^{19}$

Our findings in infants with protracted diarrhoea are somewhat analogous to the above, in that a known non-adhesive strain of $E$ coli adhered to significantly greater numbers of buccal epithelial cells from infants with protracted diarrhoea, compared with patients with acute diarrhoea, or healthy infants and adults. Moreover, Enterobacteria isolated from the patients with protracted diarrhoea were more likely to adhere to their own buccal epithelial cells than to buccal epithelial cells from healthy adults. If the adhesive properties of buccal epithelial cells are similar to those of the surface epithelial cells of the small intestine then our findings may explain in part why bacterial overgrowth of the small gut is such a common finding in infants with protracted diarrhoea. ${ }^{2-7}$

CFA/I and CFA/II have recently been identified on surface adhesive antigens in certain known human enteropathogenic strains of $E$ coli, and this prompted us to test the organisms isolated from our patients for these antigens. Using a haemagglutination assay none of the organisms possessed these antigens, suggesting that adhesion was not mediated by CFA/I or CFA/II. Type I fimbriae have not yet been firmly implicated as mediators of adhesion in the pathogenesis of diarrhoea; it was therefore of some interest to find that $E$ coli isolated from two patients possessed these fimbriae.

The nature of the increased 'cohesion' between buccal epithelial cells and $E$ coli and the other Enterobacteriaceae in the infants with protracted diarrhoea has not been determined in the present study, but a number of variables such as age, nutritional status, and genetic predisposition should be considered. In this conext it is of interest to note that siblings of patients 1 and 2 were similarly affected. ${ }^{20} 21$ 
It is tempting to speculate that malnutrition and/or genetic predisposition may influence the adhesive properties of mucosal cells, and explain why some children develop protracted diarrhoea after an acute enteric infection.

The authors would like to thank Dr N Evans for supplying $E$ coli $\mathrm{O} 1: \mathrm{K} 1: \mathrm{H} 7$. DCAC and TSML acknowledge the financial support of the Rayne Foundation.

\section{References}

1 Lifschitz F. Effects of diarrhoea on infant nutrition. In: Lebenthal E, ed. Textbook of gastroenterology and nutrition in infancy. New York: Raven Press, 1981: 1003-11.

2 James WPT, Drasar BS, Miller C. Physiological mechanisms and pathogenesis of weanling diarrhoea. Am J Clin Nutr 1972; 25: 564-71.

3 Mata LJ, Jimenez F, Cordon M et al. Gastrointestinal flora of children with protein-calorie malnutrition. $\mathrm{Am}$ J Clin Nutr 1972; 25: 118-26.

4 Gracey M, Suharjono Sunoto, Stone DE. Microbial contamination of the gut: another feature of malnutrition. Am J Clin Nutr 1973; 26: 1170-4.

5 Heyworth B, Brown J. Jejunal microflora in malnourished Gambian children. Arch Dis Child 1975; 50: 27-33.

6 Rowland MGM, McCollum JPK. Malnutrition and gastroenteritis in the Gambia. Trans $R$ Soc Trop Med Hyg 1977; 71: 199-203.

7 Gracey M, Stone DE. Small-intestinal microflora in Australian aboriginal children with chronic diarrhoea. Aust NZ J Med 1972; 3: 215-9.

8 Candy DCA. The role of mucosal adhesion in the pathogenesis of Escherichia coli induced diarrhoea. $J$ Trop Pediatr 1980; 2: 75-9.

9 McNeish AS, Turner P, Fleming J, Evans N. Musocal adherence of human enteropathogenic Escherichia coli. Lancet 1975; 2: 946-8.
10 Candy DCA, Leung TSM, Phillips AD, Harries JT, Marshall WC. Models for studying the adhesion of enterobacteria to the mucosa of the human intestinal tract. In: Adhesion and microorganisms pathogenicity: Ciba Symp 80. Tunbridge Wells: Pitman Medical, 1981: 72-93.

11 Larcher VF, Shepherd R, Francis DEM, Harries JT. Protracted diarrhoea in infancy. Analysis of 82 cases with particular reference to diagnosis and management. Arch Dis Child 1977; 52: 597-605.

12 Levine MM, Berquist EJ, Nalin DR et al. Escherichia coli strains that cause diarrhoea but do not produce heat-labile or heat-stable enterotoxins and are noninvasive. Lancet 1978; 1: 119-22.

13 Ofek I, Mirelman D, Sharon N. Adherence of Escherichia coli to human mucosal cells mediated by mannose receptors. Nature 1977; 265: 623-5.

14 Candy DCA, Chadwick J, Leung T, Phillips A, Harries JT, Marshall WC. Adhesion of Enterobacteriaceae to buccal epithelial cells. Lancet 1978; 2: 1157-8.

15 Levine MM, Rennels MB, Daya V, Hughes TP. Hemagglutination and colonization factors in enterotoxigenic and enteropathogenic Escherichia coli that cause diarrhoea. $J$ Infect Dis 1980; 141: 733-7.

16 Jones GW, Rutter JM. Role of the K88 antigen in the pathogenesis of neonatal diarrhoea caused by Escherichia coli in piglets. Infect Immunol 1972; 6: 918-27.

17 Rutter JM, Burrows MR, Sellwood R, Gibbons RA. Agenetic basis for resistance to enteric disease caused by $E$ coli. Nature 1975; 257: 125-6.

18 Kallenius G, Winberg J. Bacterial adherence to periurethral epithelial cells in girls prone to urinary tract infections. Lancet 1978; 2: 540-3.

19 Johanson WG Jr, Woods DE, Chaudhuri T. Association of respiratory tract colonization with adherence of gram-negative bacilli to epithelial cells. $J$ Infect Dis 1979; 139: 667-73.

20 Candy DCA, Larcher VF, Cameron DJS, Norman AP, Tripp JH, Milla PJ, Pincott JR, Harries JT. Lethal familial protracted diarrhoea. Arch Dis Child 1981; 56: 15-23.

21 Howard FM, Carter CO, Candy DCA, Harries JT. A family study of protracted diarrhoea in infancy. $J$ Med Genet 1981; 18: 81-6. 